\title{
Prevalence of some respiratory diseases among sheep and goats in Shalateen, Halaieb and Abu-Ramad Areas
}

\author{
Mona A. Mahmoud, Wafaa A. Osman, Azza S. A. Goda, A. L. El Naggar. \\ Animal Health department, Desert Research Center, Mataria, Egypt
}

\begin{abstract}
Nasopharyngeal swabs and pnuemonic lung autopsies collected from diseased or slaughtered sheep and goats suffering from respiratory manifestation were subjected to microbiological sreening. In addition, serum samples were collected from all animals were investigated. $P$. hemolytica was the most prevalent recovered bacterial isolates followed by $\boldsymbol{S}$. aureus and $\boldsymbol{E}$. coli. On the other hand, Aspergillus fumigatus was the most prevalent fungus. Aspergillus species and Candida albicans were also isolated. Most of the isolated bacterial strains were found sensitive to spectrama and chloramphenicol. Serodiagnosis of $P$. hemolytica by ELISA using the whole cell antigen gave positive results in 18.3 and $22.5 \%$ of diseased sheep and goats respectively and $52 \%$ and $42.1 \%$ of slaughtered pneumonic sheep and goats respectively. Also serodiagnosis of Aspergillus fumigatus by indirect haemagglutination test revealed positive results in18.3and $17.5 \%$ of diseased sheep and goats respectively and $24 \%$ and $21 \%$ in sera of slaughtered pneumonic sheep and goats respectively. Histopathological changes due to $P$. haemolytica and Aspergillus fumigatus were recorded.
\end{abstract}

Respiratory disorders represent one of the most important causes of great economic losses among animals. Lung affections in farm animals constitute serious problem that hinders animal production and may result in great losses in animal husbandry. The primary causes of sheep and goat pneumonia are bacteria, viruses and fungi whereas pour hygienic measures and climate disorders are the most predisposing factors to infection (Hafez et al, 1991 and Elyas et al, (1984).

Pasteurella speices (P. multocida, $P$. haemolytica), Pseudomonas sp. and Klebsiella pneuomniae are the important bacterial causes of sheep pneumonia (Quinn et al., 1994) while aspergillus species is the main cause of fungal pneumonia in sheep ( Kamil and Parihar, 1991 ). Kaya and Erganis (1991) isolated S. aureus alone or in combination with other organisms from sheep.

Mishra (1988) isolated Aerobacter, Corynebacterium, Esherichia coli, Klebsiella, Micrococcus, Pasteurella, Pseudomonas, Staphylococcus and Streptococcus species from pneumonic lungs of goats.

Elyas (1995) isolated E. coli, S. aureus, S. epidermidis, A. pyogenes , C. ovis, $S$. pneumoniae, $P$. aeruginosa, $K$. pueumouiae, $P$. multocida, As. flavus and As. terreus from pneumonic lung sheep. P. haemolytica is the most important cause of bacterial respiratory mortality in cattle and sheep. It is also, identified as the major cause of systemic deaths in sheep. Rowe et al. (2001)

Antigens that may serve as potential immunogens have been characterized as whole cell and leukotoxin antigen (Derek et al, 1989).

The aim of this study was to isolate and identify the possible causative bacterial and fungal pathogens of such respiratory disease conditions as direct methods of their diagnosis and antibiogram of the isolated bacteria and fungi in was also to reach an available and specific treatment.

\section{Material and methods}

Animals. Sixty and 40 of clinically diseased sheep and goats respectively suffering from respiratory manifestation were examined and 25 and 19 of pneumonic lungs of (Slaughtered) sheep and goats respectively were employed in this study.

Samples. Nasopharyngeal swabs of 60 sheep and 40 goats suffering from respiratory disorders. From 25 and 19 slaughtered sheep and goats respectively. The samples were taken under aseptic conditions on transport media for bacteriological and mycological examination. Serum samples were collected from all examined animals.

Clinical examination. Animals were subjected 
to clinical examination, this include recording the clinical signs, body temperature, pulse and respiratory rate.

Bacteriological and Mycological examination. Nasopharyngeal swabs were inoculated into nutrient broth and incubated at $37^{\circ} \mathrm{C}$ for $24 \mathrm{hr}$. Subcultured was performed onto the following media:

nutrient agar, 5\% sheep blood agar, MacConkey agar and S.S agar at $37^{\circ} \mathrm{C}$ for $24-48 \mathrm{hr}$. as well as Sabouraud's dextrose agar at $25^{\circ} \mathrm{C}$ and $37^{\circ} \mathrm{C}$ for 5 days.

The surface of the lung specimens was sterilized with a hot spatula, then with sterile platinum loop to be inoculated in the previously mentioned media. Colonies were identified mycologically according to (Baily and Scott 1974; Conan et al., 1971 and Ellis, 1976).

Antibiogram sensitivity test for bacterial isolates was done by disc diffusion method using the following antibiotic discs, ampicillin $(10 \mathrm{mg})$, kanamycin $(30 \mathrm{mg})$, chloramphenicol $(30 \mathrm{mg})$, Erythromycin $(15 \mathrm{mg})$ oxytetracyclin $(30 \mathrm{mg})$, spectrama $(10 \mathrm{mg})$ and lincomycin $(10 \mathrm{mg})$ according to the method described by (Cruickshank et al., 1975).

ELISA. serological diagnosis of pasteurellosis in sheep and goats by ELISA according to Derek et al. (1989). Whole cell $P$. haemolytica antigen was prepared from fresh 18 hours cultures of $P$. haemolytica suspended to concentration of $10^{9}$ cfu in phosphate buffer saline (pH7.4) according to Derek et al. (1989).

Indirect haemagglutination (IHA). Serological diagnosis of Aspergillosis in sheep and goats was performed using (Fumoze Diagnostics, France) according to the method of (Senet and Brisset, 1973).

Histopathological studies. Histopathological sections were prepared from pneumonic lungs. Tissue sections were stained by H\&E and GMS (Clayden, 1971)

\section{Results and discussion}

In Table (1) the main clinical signs were rise of body temperature $\left(39.5-40^{\circ} \mathrm{C}\right)$, depression, eye and nasal discharges, loss of appetite and acceleration of respiration. By auscultation, exaggerated vesicular sounds in some cases, moist ralles with frictional sounds. The post mortem findings included congestion of the lung accompanied with heavy fibrinous, grayish or yellowish exudates within the bronchi. In some cases grayish white abscesses with offensive odors and sometimes pulmonary edema were recorded. The most important bacterial and mycotic isolates of the nasopharyngeal swabs and pneumonic lungs of sheep and goats, the antibiogram of the bacterial isolates and serodiagnosis against $P$. haemolytica, $A$. fumigatus in sheep and goats are demonstrated in (Tables 1-5).

Respiratory diseases in sheep and goats and in particular pneumonia are the result of interaction of many infectious agents under the influence of physical stresses (Rahman and Lyer, 1979 and Martin, 1983).

The results recorded in (Tables 2 and 3) revealed that $P$. haemolytica was the main bacterial cause of sheep and goats pneumonia as its percentage was $16.6 \%$ and $20 \%$ in nasopharyngeal swabs of sheep and goats respectively and $32 \%$ and $31.6 \%$ in the pneumonic lungs of sheep and goats. These results were agreed with Mishra (1988), Hafez et al. (1991); Mackie et al, (1995); Martrenchar et al (1995); Black and Duganzich (1995); Fodoral et al. (1999) and Mohamed and Shaker (2002) who isolated $P$. haemolytica from apparently healthy $(56 \%)$ and diseased sheep $(75 \%)$ while $66 \%$ and $90 \%$ from emergency slaughtered and dead animals respectively.

In the present study, $S$. aureus, E. coli, Streptococci, K. preumoniae, P. multocida and $P$. aeruginosa were also isolated from both nasopharyngeal swabs and pneumonic lungs of sheep and goats. Similar findings were reported by Biberstein et al. (1967) and Sayed (1996).

Qunin et al. (1994), recorded that K. pneumonae and $P$. aeruginosa cause pneumonia and lung abscesses in sheep.

Isolation of Salmonella species from nasopharyngeal swabs of diseased sheep and from pneumonic lungs was in agreement with Thabet (1993).

The isolation of fungi concurrently mixed with one or two bacterial isolates are in agreement with Thabet (1993) and Sayed (1996) who reported that different bacterial strains could be isolated in combination with fungi from respiratory tract of camels and sheep. These results may be due to several factors as hygienic measures, environmental conditions, nutritional deficiencies and immune status of the animal (Darwish et al., 2001)

Mycotic pneumonia in some cases is very dangerous due to lack of quick laboratory diagnosis and usually pneumonia is produced as a result of mixed infection with bacteria In this study the reported data proved that the overall incidence of aspergillosis infection in sheep and 
Table (1) Clinical signs and post mortem findings of sheep and goats.

\begin{tabular}{|c|c|c|c|c|}
\hline Species & $\begin{array}{l}\text { No. and } \\
\text { status }\end{array}$ & Samples & Clinical & Post mortem \\
\hline Sheep & $\begin{array}{c}60 \text { diseased } \\
25 \text { pneumonic } \\
\text { (Slaughtered } \\
\text { animals). }\end{array}$ & $\begin{array}{c}60 \\
\text { nasopharyngeal } \\
\text { swabs } \\
25 \text { samples of } \\
\text { pneumonic lung }\end{array}$ & $\begin{array}{l}60 \text { and } 40 \text { diseased sheep and } \\
\text { goats showed rise of body } \\
\text { temperature }\left(39.5-40^{\circ} \mathrm{C}\right), \\
\text { depression, } \\
\text { Increased eye and nasal } \\
\text { discharge, loss of appetite and } \\
\text { acceleration of respiration. }\end{array}$ & $\begin{array}{l}25 \text { and } 19 \text { pneumonic lung of } \\
\text { sheep and goats showed } \\
\text { congestion of the lung } \\
\text { accompanied with heavy } \\
\text { fibrinous, grayish or yellowish } \\
\text { exudates within bronchi, in } \\
\text { some cases greyish white } \\
\text { abscesses with offensive odours } \\
\text { and sometimes pulmonary } \\
\text { odema. }\end{array}$ \\
\hline Goats & $\begin{array}{l}40 \text { diseased } \\
19 \text { pneumonic } \\
\text { (Slaughtered } \\
\text { animals). }\end{array}$ & $\begin{array}{c}40 \\
\text { nasopharyngeal } \\
\text { swabs } \\
19 \text { samples of } \\
\text { pneumonic lung }\end{array}$ & $\begin{array}{l}\text { Auscultation revealed } \\
\text { exaggerated vesicular sounds, } \\
\text { moist ralles with frictional } \\
\text { sounds. }\end{array}$ & \\
\hline Total & 59 & & & \\
\hline
\end{tabular}

Table (2) Types and number of microorganisms isolated from infected sheep.

\begin{tabular}{|c|c|c|c|c|}
\hline \multirow{2}{*}{ Microorganisms } & \multicolumn{2}{|c|}{ Nasopharyngeal swabs (60) } & \multicolumn{2}{|c|}{$\begin{array}{c}\text { Pneumomic lungs } \\
(25)\end{array}$} \\
\hline & No & $\%$ & No & $\%$ \\
\hline P. haemolytica & 10 & 16.6 & 8 & 32 \\
\hline S. aureus & 9 & 15 & 3 & 12 \\
\hline E. coli & 7 & 11.7 & 2 & 8 \\
\hline K. pnoumoniae & 5 & 8.3 & 2 & 8 \\
\hline S. Pyogenes & 5 & 8.3 & - & - \\
\hline S. pneumoniae & 4 & 6.7 & 1 & 4 \\
\hline P. multocida & 3 & 5 & 2 & 8 \\
\hline$P$. aeruginosa & 3 & 5 & 1 & 4 \\
\hline Salmonella species & 2 & 3.3 & 1 & 4 \\
\hline P. multocida + E. coli + A. fumigatus & 2 & 3.3 & - & - \\
\hline K. pneumoniae $+S$. aureus + A. fumigatus & 2 & 3.3 & - & - \\
\hline S. aurens $+C$. albicans & 2 & 3.3 & 2 & 8 \\
\hline S. aureus $+E$. coli $+A$. niger & 1 & 1.7 & - & - \\
\hline A. fumigatus & 5 & 8.3 & 3 & 12 \\
\hline Total & 60 & $100 \%$ & 25 & $100 \%$ \\
\hline
\end{tabular}

Table (3): Types and number of microorganisms isolated from infected goats.

\begin{tabular}{lcccc}
\hline \multirow{2}{*}{\multicolumn{1}{c}{ Microorganisms }} & \multicolumn{2}{c}{ Nasopharyngeal swabs (60) } & \multicolumn{2}{c}{ Pneumonic lungs (25) } \\
\cline { 2 - 5 } & No & $\%$ & No & $\%$ \\
\hline P. haemolytica & 8 & 20 & 6 & 31.6 \\
S. aureus & 7 & 17.5 & 4 & 21 \\
E. coli & 5 & 12.5 & 3 & 15.8 \\
S. pyogenes & 4 & 10 & 1 & 5.3 \\
K. pnoumoniae & 3 & 7.5 & 1 & 5.3 \\
P. aeruginosa & 3 & 7.5 & 1 & 5.3 \\
S. pneumoniae & 4 & 10 & 1 & 5.3 \\
S. aureus + E. coli $+\boldsymbol{A}$.niger & 3 & 7.5 & - & - \\
E. coli + C. albicans & 1 & 2.5 & - & - \\
S. pneumoiae + A. flavus & 1 & 2.5 & - & - \\
K. pnoumoniae + A.fumigatus & - & - & 2 & - \\
A. fumigatus + A. niger & 1 & 2.5 & - & $100 \%$ \\
& 40 & $100 \%$ & 19 & \\
\hline
\end{tabular}


Table (4): Antibiogram of isolated bacteria from nasopharyngeal swabs and pneumonic lungs of sheep and goats.

\begin{tabular}{lccccccc}
\hline \multicolumn{1}{c}{ Microorganisms } & Ampicilin & $\begin{array}{c}\text { Erythro- } \\
\text { micin }\end{array}$ & $\begin{array}{c}\text { Linco- } \\
\text { mycin }\end{array}$ & $\begin{array}{c}\text { Spectr- } \\
\text { ama }\end{array}$ & $\begin{array}{c}\text { Chloram- } \\
\text { phnicol }\end{array}$ & $\begin{array}{c}\text { Kana- } \\
\text { mycin }\end{array}$ & $\begin{array}{c}\text { Oxytetra- } \\
\text { cyclin }\end{array}$ \\
\hline $\boldsymbol{P}$. haemolytica & + & + & - & +++ & ++ & + & + \\
S. aureus & ++ & + & - & +++ & +++ & ++ & + \\
E. coli & + & + & + & +++ & ++ & ++ & + \\
K. pnoumoniae & - & - & - & +++ & ++ & ++ & - \\
S. pyogenes & + & ++ & - & +++ & - & ++ & - \\
S. pneumoniae & + & ++ & - & +++ & + & ++ & + \\
$\boldsymbol{P}$. multocida & + & + & - & +++ & ++ & + & - \\
$\boldsymbol{P}$, aeruginosa & + & + & - & +++ & + & ++ & - \\
Salomonella spp. & + & + & - & ++ & +++ & - & ++ \\
\hline
\end{tabular}

Table (5): Antibody response of sheep and goats to P. haemolytica whole cell antigen using ELISA.

\begin{tabular}{|c|c|c|c|c|c|c|c|c|}
\hline \multirow{3}{*}{ Status \& number } & \multicolumn{4}{|c|}{ Sheep } & \multicolumn{4}{|c|}{ Goats } \\
\hline & \multicolumn{2}{|c|}{ Diseased (60) } & \multicolumn{2}{|c|}{$\begin{array}{l}\text { Slaughtered with } \\
\text { pneumonia (25) }\end{array}$} & \multicolumn{2}{|c|}{ Diseased (40) } & \multicolumn{2}{|c|}{$\begin{array}{r}\text { Slaughter with } \\
\text { pneumonia (19) } \\
\end{array}$} \\
\hline & No & $\%$ & No & $\%$ & No & $\%$ & No & $\%$ \\
\hline +ve culture $\&+$ ve ELISA & 7 & 11.7 & 8 & 32 & 6 & 15 & 6 & 31.6 \\
\hline + ve culture \& -ve ELISA & 3 & 5 & - & - & 2 & 5 & - & - \\
\hline -ve culture \& +ve ELISA & 4 & 6.7 & 5 & 20 & 3 & 7.5 & 2 & 10.5 \\
\hline - ve culture \& - ve ELISA & 46 & 77 & 12 & 48 & 29 & 72.5 & 11 & 57 \\
\hline Total + ve culture & 10 & 16.7 & 8 & 32 & 8 & 20 & 6 & 31.6 \\
\hline Total +ve ELISA & 11 & 18.3 & 13 & 52 & 9 & 22.5 & 8 & 42.1 \\
\hline
\end{tabular}

Cut off sheep $=0.6$

Goats $=0.5$

Table (6): Antibody response of sheep and goats to Aspergillus fumigatus using IHA.

\begin{tabular}{|c|c|c|c|c|c|c|c|c|c|c|c|}
\hline \multirow{2}{*}{$\begin{array}{c}\text { Species, status and } \\
\text { No. }\end{array}$} & \multirow{2}{*}{$>\mathbf{1 / 8 0}$} & \multirow{2}{*}{$1 / 80$} & \multirow{2}{*}{$1 / 160$} & \multirow{2}{*}{$1 / 320$} & \multirow{2}{*}{$1 / 460$} & \multirow{2}{*}{$1 / 1280$} & \multirow{2}{*}{$1 / 2560$} & \multicolumn{2}{|c|}{ Positive culture } & \multicolumn{2}{|c|}{ Positive IHA } \\
\hline & & & & & & & & No. & $\%$ & No & $\%$ \\
\hline $\begin{array}{c}\text { Sheep, diseased } \\
\text { (60) }\end{array}$ & 30 & 15 & 4 & 2 & $4 *$ & $3 *$ & $2 *$ & 9 & $15 \%$ & 11 & 18.3 \\
\hline $\begin{array}{l}\text { Slaughtered sheep, } \\
\text { with pneumonia } \\
\text { (25) }\end{array}$ & 11 & 5 & 3 & 3 & $1 *$ & $1 *$ & $1 *$ & 3 & 12 & 6 & 24 \\
\hline Diseased goats (40) & 17 & 8 & 5 & 3 & $1 *$ & $1 *$ & $2 *$ & 4 & 10 & 7 & 17.5 \\
\hline $\begin{array}{l}\text { Slaughtered goats } \\
\text { with pneumonia } \\
\text { (19) }\end{array}$ & 6 & 6 & 3 & 2 & $1 *$ & $1 *$ & - & 2 & 10.5 & 4 & 21 \\
\hline
\end{tabular}

+ve IHA $>1 / 320$

$*=$ Positive culture

IHA = Indirect Haemagglutination 


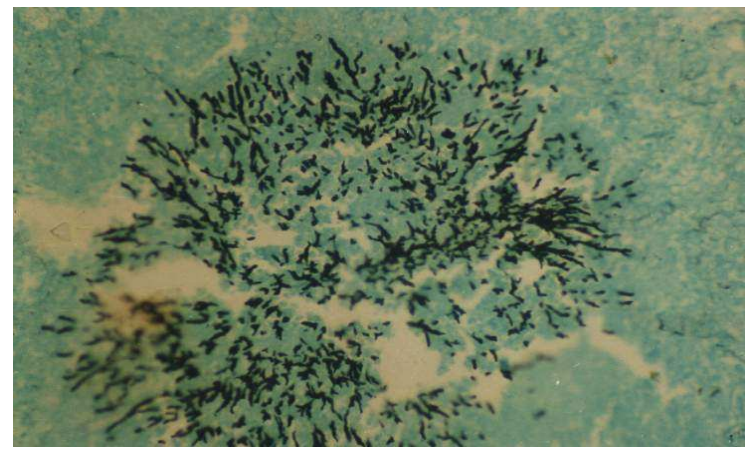

Fig. (1): Lung of sheep showing mononuclear cells infilteration with intra alveolar edema. (H\&E. x100)

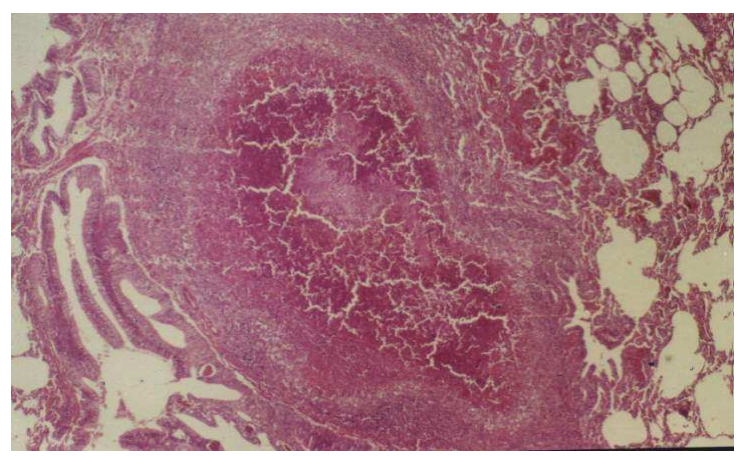

Fig. (2): lung of sheep showing large mycotic granuloma. (PAS, x100)

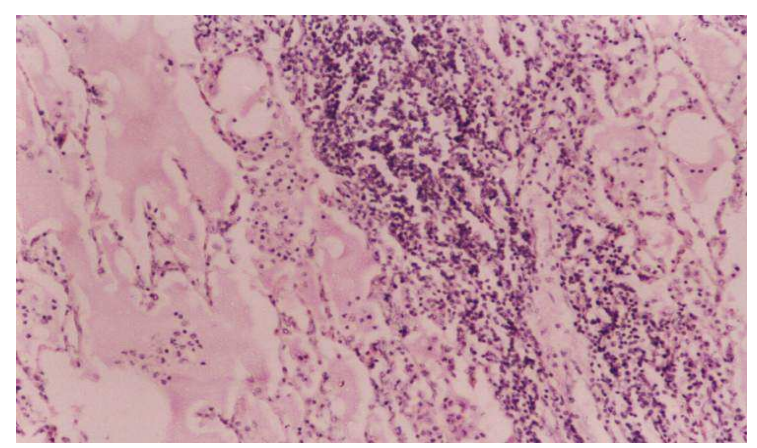

Fig. (3): Chronic mycotic granuloma in lung tissue stained by GM.s. showing central small nodule of A. fumigatus. (x220)

Nicolas et al. (1985) who reported that $12 \%$ of respiratory diseases in sheep were attributable to aspergillus infection lower value was reported by Singh et al. (1995), the incidence of asperg- illosis was $4.9 \%$ in both sheep and goats. In the present study $A$. fumigatus was the most common isolate among Aspergillus species constituting 15 and $10 \%$ in diseased sheep and goats and 12 and $10 \%$ in pneumonic lungs of sheep and goats respectively proving that it was the major cause of pulmonary aspergllosis. These results simulated that reported by Austwick et al. (1960) and Austwick (1962) and Gonzalez et al. (1993) who reported that bovine and ovine pulmonary aspergillosis were mostly attributed to A. fumigatus infection.

Antibiogram of the isolated bacterial species yields the antibiotic of choice for proper treatment. In this investigation, most of bacterial isolates were highly sensitive to spectrama and chloramphenicol and moderately sensitive to kanamycin, erythromycin and ampicillin and less sensitive to lincomycin and oxytetracycline. Table (5) showed, the results of antibody response of sheep and goats to $P$. haemolytica whole cell antigen using ELISA. Aquilar et al. (1994) suggested that whole cell antigen stimulate somatic antibody response.

The results of ELISA as presented in (Table 5), showed significant increase in antibody titer to whole cell antigen in $18.3 \%$ and $22.5 \%$ of examined diseased sheep and goats. $52 \%$ and $42.1 \%$ in sera of slaughtered sheep and goats respectively. These results go in hand with Sahr and Maysa (2002) who diagnosed $P$. haemolytica in sheep by isolation from lungs and serologically by ELISA.

Concerning the results of serodiagnosis against A. fumigatus, (Table 6), by using indirect heamagglutination (IHA) test, it was noticed that $18.3 \%$ and $17.5 \%$ of diseased sheep and goats respectively and $24 \%$ and $21 \%$ of slaughtered sheep and goats respectively had antibodies against $A$. fumigatus with significant titer $\geq$ $1 / 320$. These results agree with Osman (2000) who used IHA for detection of antibodies against A. fumigatus in sera of sheep and goats, with approximately equal results El-Shayeb (1996) detected antibodies in serum of cattle with incidence of $46.6 \%$. On the other hand Iwata et al. (1990) proved that $2.9 \%$ of examined serum samples of cattle were positive. These results agreed with the findings recorded by Kate 
(1981) who recorded that IHA test was a reliable and rapid method for detecting antibodies against aspergillosis in serum samples. Histopathological examination of the lung tissue of infected sheep and goats revealed mycotic pneumonia characterized by the presence of multiple focal mycotic granuloma, septated hyphae of A. fumigatus scattered in the center of granuloma surrounded by polymorphonuclear cells, lymphocytes and macrophages with proliferation of fibrous connective tissue. These pathological findings are in agreement with that recorded by Chattopathyay et al. (1987) and Singh et al. (1995) in sheep and goats.

In the present work, $P$. haemolytica was responsible for the severe pathological changes developed in the lung of sheep and goats, which were interstitial pneumonia and pleuritis. These results were inagreement with Mohamed and Shaker (2002).

\section{References}

Aquilar R. F.; Jaramillo, M. L. and Trigo, T. F. (1994): Vaccination of lambs against pulmonary Pasteurella under experimental condition. Italian Association of buiatrics (2): 1449-1452.

Austwick, P. K.C. (1962): The presence of Asperillus fumigatus in the lungs of dairy cows. Lab. Invest., 11: $1065-1072$.

Austwick, P. K. C.; Gitter, M. and Watkins C. V. (1960): Pulmonary Aspergillosis in lambs. Vet. Rec., 72: 19-21.

Bailey, W. R. and Scott, B. G. (1974): Diagnostic Microbiology. A textbook for the isolation and identification of pathogenic microorganisms. $4^{\text {th }}$ ed. the C. V. Mosby Comp., Saint Louis

Biberstein, E. L.; Nishets, D. L. and Thompson. D. A. (1967): Experimental pneumonia in sheep. J. Comp. Pathol., 77: 181-192.

Black, H.; Duganzich, D. (1995): A filed evaluation of the two vaccines against ovine pneumonic pasteurellosis. New Zealand Vet. J., 34 (2): 60-63 .

Chattapadhyay, S. K; Vanamayya, P. K. and Sikdar, A. (1987): Experimental pulmonary aspergillosis in lambs. A mycopathological study. Ind. J. Vet. Pathol, 11: 38-43. Clayden, E. C. (1971): Practical section cutting and staining $5^{\text {th }}$ ed. Churchill Livingston, Edinburgh, London.

Conan, N. F; Smith, D. T.; Baker, R. D and Caiiway, J. L. (1971): Manual of Clin. Mycol. $3^{\text {rd }}$ ed. Saunders, Philadelphia.

Cruickshank, R.; Duguid, J. P.; Marmion and Swain, P. H. A. (1975): Med. Microbiol., Livingston, Edinburgh, London.

Darwish, F. M.; Hammad, A. M. and Ibrahim, H. S. (2001): Pathological studies on pneumonia in camel with special reference to mycotic and bacterial infection Assiut. Vet. Med. J., 61 (2): 143-172.

Derek, A.; Anthony, W.; Roger, D. and Kaneth, D. (1989): Pasteurella haemalytica antigens associated with resistance to pneumonic pasteurelloris. Inf. Immun., 57 (3): 711-716.

Ellis, M. B. (1976): More Dematicaceus hyphomycetes.
Comm. Mycol. Inst. Kew, Surrey, England (mentioned by Elyas, A. H. (1993): Some studies on sheep pneumonila of bacterial and fungal origin. Assiut Vet. Med. J., 29 (58): 89-94.

El-Shayeb, M. (1996): Bacteriological and mycological studies on cattle respiratory pathogens. Ph.D. Thesis, Fac. Vet. Med. Zagazig Univ., Egypt.

Elyas, U. K.; Arya, P. L. and Sharma, C. D. (1984): Sheep pneumonia in Arid Zone of Rajasthan. Ind. J. Anim. Sci., 54: 459 - 462.

Fodoral, V. J.; Hajtos, I. and Molnart, J. (1999): Pasteurella haemolytea and Pasteurella trechclose isolated form farm animals. J. Vet. Med., 46 (4): 241-247.

Gonzalez, F. F.; Heras, M. D.; Dejolan, G. J. A., Barcena. C. D.and Heras, M. (1993): Pulmonary aspegillosis is young lambs. Revesta Iberoa Mericana Mhcologia, 10 (4): 98-99.

Hafez, A. M.; Razig S. A.; El-Amrousi, S. and AlHendi, A. B. (1991): Respiratory diseases occurring in farm animals in the Eastern provinces of Saudi Arabia. Assiut Vet. Med. J., 24 (48).

Iwata, H.; Hiwa, T. and Takayi, K. (1990): Tuberculosis sequlae secondary fungal infection. Kakkaku, 65(12): 867871.

Kamil, S. A and Parihar, N. P. (1991): Pathology of mycotic pneumonia in sheep. Ind. J. Anim. Sci., 61 (1): 13-18.

Kate, C.; (1981): Pathogenic fungi in principles of immunological diagnosis in medicine. Edited by Milgram F., Abeyaunis C. J. and Kana P. Lea, Febiger Philadelphia. Kaya, O. and Erganis, C. (1991): Aetiological survey of pneumonia in sheep and lambs. Veterinarium, 2: 3-4, 27 29.

Mackie, J. T.; Barton, M.; Hindmarch, M.; Hoiswor, T. H. I. (1995): Pasteurella haemolytica septicemia in sheep Australian. Vet. J., 72 (12): 474.

Martin, W. B. (1983): Diseases of sheep. Blackwell Scientific Publications London, Edinburgh, Bolton.

Martrenchar, A.; Zoyem, N.; Ngangnou, A.; Bouchel, D. N. G.O.; Tama, A. C.; Njoya, A. (1995): Study of the main infections agents involved in the etiology of pulmonary diseases of small ruminants in Northern Cameroon. Revue d Elevage et de Medecine Veterinaire, des Pays, Tropicoux, 48: 113-137.

Mishra, K. C (1988): Study of microbial flora of the upper respiratory tract of pneumonia prove flocks of sheep and goats. Ind. J. Anim. Health 27 (1): 27-33.

Mohamed, S. R. and Shaker, M. H. (2002): Immunological studies on Pasteurella haemolytica in sheep. Vet. Med. J. Giza., 50 (4): 695 - 708.

Nicolas, J. A.; Loubet, R.; Alexandre, P.; Champagnal, M. P.; Dubost, G.; Lamachone, M. and Chanchefe, S. (1985): Respiratory diseases caused by Asergilles funigatus in sheep point. Veterinarian, 17 (88): 180-182.

Osman, W. A. (2000): Immunological studies on natural and experimental aspegillosis in goats and sheep: $\mathrm{PhD}$ thesis Dep. Microbiol. Fac. Vet. Med. Zagazig Univ., Egypt.

Quinn, P. J.; Carter, M. E; Markey, B. K. and Carter, G. R (1994): Clin. Vet. Microbiol., Wolfe, Virginia USA.

Rahman, T. and Iyer, P. K. R. (1979): Studies on pathology of ovine pneumonias. Ind. Vet. J., 56: 455-461.

Rowe, H. A.; Poxton, I. R. and Doonachie, W. (2001): Survival of Pasteurella haemolytica in trachobachial washings of sheep and cattle Vet. Microbiol., 81: 305-314. 
Sayed, A. M. (1996): Bacteriological and mycological studies on sheep pneumonia at Assiut governorate. Assiut Vet. Med. J, 36 (71).

Senet J. M. and Brisset C. (1973): the diagnosis of aspegillosis by passive haemagglutination biomedicine, $19: 365-368$
Singh; S. V.; Sharma, D. N.; Srivastava, A. K.; and Singh, H. (1995): Pulmonary aspegillosis in sheep and goats: incidence and pathomor phology. Ind. J. Vet. Pathol., 19 (1), 35 - 37.

Thabet, A. R. (1993): Some microbial studies on lung of clinically healthy and respiratory infected camels. Assiut. Vet. Med. J., 30 (59): 188 - 195. 